\title{
MENINGKATKAN MINAT BELAJAR SISWA DENGAN MENGGUNAKAN STRATEGI LEARNING START WITH A QUESTION (LSQ) PADA KELAS ONLINE MASA PANDEMI COVID 19 DI MADRASAH ALIYAH NEGERI 1 BUNGO
}

\author{
Yanfaunnas \\ Madrasah Aliyah Negeri 1 Bungo \\ Email: yanfaunnasbungo@gmail.com
}

\begin{abstract}
This research is based on the lack of students' nineth grade interest in learning Arabic during covid 19 pandemic at Madrasah Aliyah Negeri 1 Bungo. The aim of this research was to find out whether the use of Learning Start With A Question (LSQ) Strategi could increase students' interest in learning Arabic. The approach of this research was Qualitative Action Research using Kemmis and Mc Taggart Model with two cycles.the result of this research showed that student's interest in learning Arabic using LSQ in the first sysle increase from $47,17 \%$ to $62,13 \%$. And in the second sycle, the students' interest become $79,25 \%$. Thes indicates that LSQ Strategi increased students' nine grade interest in Learning Arabic on the material of "Hiwayah" at Madrasah Aliyah 1 Bungo.
\end{abstract}

Keywords : Learning Start With A Question, interest in learn, Arabic

\begin{abstract}
Abstrak
Penelitian ini dilatar belakangi karena rendahnya minat belajar kelas online pada masa pandemi covid 19 siswa kelas x mata pelajaran bahasa arab di Madrasah Aliyah Negeri 1 Bungo. Tujuan penelitian ini adalah untuk menganalisis peningkatan minat belajar siswa dengan menggunakan strategi Learning Start With A Question (LSQ). Penelian ini menggunakan pendekatan kualitatif action research melalui model Kemmis and Taggart dengan dua siklus. Hasil penelitian menunjukkan bahwa Pertama, tingkat minat belajar siswa pada mata pelajaran bahasa arab dengan pendekatan LSQ di siklus I meningkat dari 47,17\%. menjadi 62,13\%. Hal ini berarti bahwa penggunaan strategi LSQ mampu menjadi solusi dalam mengatasi rendahnya minat belajar siswa, sehingga dapat dijadikan sebagai variabel tindakan untuk siklus II. Kedua, tingkat minat belajar siswa pada mata pelajaran bahasa arab dengan strategi LSQ di siklus II meningkat menjadi 79,25\%. Hal ini menunjukkan bahwa dengan menggunakan strategi LSQ dapat meningkatkan minat belajar siswa di kelas $\mathrm{x}$ pada mata pelajaran bahasa arab Tema "Hiwayah" di Madrasah Aliyah Negeri 1 Bungo
\end{abstract}

Kata Kunci : Learning Start With A Question, Minat Belajar, Bahasa Arab.

Nur El-Islam, Volume 8, Nomor 2, Oktober 2021 


\section{A. Latar Belakang.}

Pendidikan adalah usaha sadar dan terencana untuk mewujudkan suasana belajar dan proses pembelajaran agar peserta didik secara aktif mengembangkan potensi dirinya untuk memiliki kekuatan spiritual keagamaan, pengendalian diri, kepribadian, kecerdasan, akhlah mulia, serta keterampilan yang diperlukan dirinya, masyarakat bangsa dan Negara. ${ }^{1}$ Guru mempunyai peranan yang sangat penting dalam perkembangan dan kemajuan anak didiknya. Dari sinilah guru dituntut untuk dapat menjalankan tugas dengan sebaik-baiknya. Guru dalam dunia pendidikan memang mempunyai tugas yang sangat mulia, guru bekerja memberikan dan menerapkan pengetahuan-pengetahuannya dan kecakapan-kecakapannya kepada siswa dengan hati yang ikhlas, untuk itu seorang guru sangat dituntut agar memiliki kompetensi-kompetensi profesional sebagai guru, dan harus kaya dengan berbagai model dan strategi pembelajaran

Pembelajaran bahasa arab adalah sebuah mata pembelajaran yang disajikan di madrasah aliyah, yang mempunyai hubungan yang sangat luas terkait dengan kehidupan manusia baik itu sebagai bahasa alquran, bahasa arab juga sebagai jalan untuk menggali hukum dalam kitab-kitab klasik lainnya. Pembelajran bahasa arab sangat berperan dalam proses pendidikan dan juga perkembangan teknologi, pembelajaran bahasa arab diharapkan bisa menjadi wahana bagi siswa untuk mempelajari diri sendiri dan alam sekitar, serta perkembangannya lebih lanjut dalam penerapan kehidupan seharihari. Pemberian pembelajaran bahasa arab di madrasah aliyah bertujuan agar siswa mampu menguasai kompetensi minimal yakni mendengar' membaca, berbicara, dan menulis. Untuk mencapai tujuan pengajaran yang diharapkan, guru harus mampu mengembangkan berbagai model dan strategi pembelajaran yang tepat dan sesuai kebutuhan anak didik, apalagi pada masa pandemi covid 19 sekarang ini.

\footnotetext{
${ }^{1}$ Teguh Triwiyanto, Pengantar Pendidikan, (Jakarta:PT Bumi Aksara, 2014),h.113
} 
Strategi merupakan rencana besar yang bersifat meningkat, efesien, dan produktif untuk mengefektifkan tercapainya tujuan. Strategi pada hakikatnya adalah tindakan tentang apa yang seharusnya dilakukan". ${ }^{2}$ Dalam dunia pendidikan, strategi adalah rangkaian dalam proses pembelajaram yang terkait dengan pengelolaan siswa, pengelolaan guru, pengelolaan kegiatan pembelajaran, pengelolaan lingkungan belajar, pengelolaan sumber belajar agar pembelajaran menjadi lebih efektif dan efesien sesuai dengan tujuan pembelajaran yang diharapkan. ${ }^{3}$ Sehingga nantinya proses pembelajaran tidak monoton dan membuat antusias anak didik dalam mengikuti materi pelajaran yang disampaikan.

Berdasarkan observasi awal di Madrasah Aliyah Negeri 1 Bungo ditemukan bahwa masih banyak siswa yang kurang berminat dalam pembelajaran bahasa arab pada kelas online, hal ini dibuktikan masih banyak siswa yang tidak aktif sewaktu pembelajaran berlangsung. Dari jumlah 32 siswa yang aktif hanya 15 siswa, ini menunjukkan bahwa minat belajar siswa masih kurang. Oleh karena itu guru harus mampu menggunakan metode dan strategi untuk meningkatkan minat belajar siswa.

Minat adalah suatu rasa ketertarikan yang timbul dari diri sendiri terhadap sesuatu setelah melihat sesuatu yang ada di luar dirinya ${ }^{4}$. Minat (interest) dapat juga diartikan sebagai kecenderungan dan kegairahan yang tinggi atau keinginan yang besar terhadap sesuatu. ${ }^{5}$ Bila anak-anak berminat pada suatu kegiatan, pengalaman mereka akan jauh lebih menyenangkan daripada ketika mereka merasa bosan. Begitupula minat dalam pembelajaran, orang yang tidak memiliki minat pada pelajaran tertentu, sulit untuk mencapai

2 Dedi Mulyasana, Pendidikan Bermutu dan Berdaya Saing, (Bandung: Remaja Rosdakarya,2012), 217.

${ }^{3}$ Suyono dan Hariyanto, Belajar dan Pembelajaran: Teori dan Konsep Dasar, (Bandung: Remaja Rosdakarya, 2012,), h.20.

${ }^{4}$ H. Cholil dan Sugeng Kurniawan, Psikologi Pendidikan; Telaah Teoritik dan Praktik, (Surabaya: IAIN Sunan Ampel Press, 2011), h. 48

${ }^{5}$ Baharuddin dan Esa Nur Wahyuni, Teori Belajar \& Pembelajaran (Yogyakarta, Ar-Ruzz Media, 2015), h. 29 
keberhasilan belajar secara optimal. Arti kata belajar di dalam Kamus Umum Bahasa Indonesia adalah berusaha memperoleh kepandaian atau ilmu ${ }^{6}$. Konsep belajar juga telah banyak didefinisikan oleh para pakar psikologi. Cronbach dalam Riyanto menyatakan bahwa belajar merupakan perubahan perilaku sebagai hasil dari pengalaman. Menurutnya, belajar yang sebaik-baiknya adalah dengan mengalami sesuatu menggunakan pancaindra. ${ }^{7}$ Winkel mendefinisikan belajar sebagai suatu aktivitas mental/psikis yang berlangsung dalam interaksi aktif dengan lingkungan, yang menghasilkan perubahanperubahan yang bersifat konstan dan berbekas baik dalam aspek pengetahuan-pemahaman, keterampilan, maupun nilai-sikap. ${ }^{8}$ Djamarah menyatakan bahwa belajar pada hakikatnya adalah perubahan yang terjadi di dalam diri seseorang setelah melakukan aktivitas belajar. ${ }^{9}$ Peserta didik yang memiliki minat belajar dan sikap positif terhadap pelajaran akan merasa senang mempelajari mata pelajaran tertentu, sehingga akan mempengaruhi hasil belajarnya. Menurut Ngainun Naim, belajar yang dilakukan dengan hati ceria, senang, dan rasa suka akan membawa hasil yang lebih optimal. ${ }^{10}$ Perasaan senang ketika mengikuti pelajaran akan membawa hasil yang jauh lebih baik dibandingkan dengan belajar yang dilaksanakan karena terpaksa. Hal tersebut dikarenakan minat belajar akan menjadi daya dorong yang kuat bagi anak untuk memberikan perhatian kepada suatu aktivas pembelajaran.

Minat siswa terhadap pembelajaran memberi pengaruh terhadap aktivitas belajar. Oleh karena itu, guru perlu membangkitkan minat siswa agar tertarik mengikuti pembelajaran. Cara yang dapat

\footnotetext{
${ }^{6}$ Purwa Atmaja Prawira, Psikologi Pendidikan dalam Perspektif Baru (Jogjakarta: Ar-Ruzz Media, 2014), h. 224

${ }^{7}$ Yatim Riyanto, Paradigma Baru Pembelajaran : sebagai Referensi bagi Guru/Pendidik dalam Implementasi Pembelajaran yang Efektif dan Berkualitas (Jakarta: Prenada Media Group, 2014), cet. 4, h. 5

${ }^{8}$ Ibid.

${ }^{9}$ Syaiful Bahri Djamarah dan Aswan Zain, Strategi Belajar Mengajar, (Jakarta: Rineka Cipta, 2013), h. 38

${ }^{10}$ Ngainun Naim, Dasar-dasar Komunikasi Pendidikan (Jogjakarta: Ar-Ruzz Media, 2011), h. 92
} 
digunakan untuk membangkitkan minat belajar siswa menurut Khanifatul adalah sebagai berikut:

1. Membuat materi yang akan dipelajari menarik dan tidak membosankan;

2. Desain pembelajaran membebaskan siswa mengeksplor apa yang dipelajari;

3. Melibatkan seluruh domain belajar siswa (kognitif, afektif, psikomotorik) sehingga siswa menjadi aktif. ${ }^{11}$

Minat berfungsi sebagai pendorong bagi siswa untuk melakukan apa saja yang diinginkannya. Menurut Djamarah, fungsi minat tidak berbeda dengan fungsi motivasi, yaitu: pertama sebagai pendorong perbuatan. Pada mulanya peserta didik tidak ada hasrat untuk belajar, tetapi karena ada yang dicari (untuk memuaskan rasa ingin tahunya), maka muncullah minatnya untuk belajar. Kedua sebagai penggerak perbuatan. Dorongan psikologis yang melahirkan sikap terhadap anak didik itu merupakan suatu kekuatan yang tak terbendung, yang kemudian terjelma dalam bentuk gerakan psikofisik. Ketiga sebagai pengarah perbuatan. Sesuatu yang akan di cari anak didik merupakan tujuan belajar yang akan dicapainya. Tujuan belajar itulah sebagai pengarah yang memberikan motivasi kepada anak didik dalam belajar. ${ }^{12}$

Indikator Minat Belajar menurut Slameto, siswa yang memiliki minat terhadap subyek tertentu memiliki ciri-ciri:

a) Memberi perhatian lebih pada kegiatan yang diamati,

b) Aktif mengikuti kegiatan atau hal yang diminati,

c) Menunjukkan rasa senang ketika melakukan kegiatan atau hal yang diminati. ${ }^{13}$

Senada dengan pendapat Syaiful Bahri Djamarah menyatakan bahwa siswa yang berminat dalam kegiatan belajar mempunyai ciriciri:

11 Khanifatul, Pembelajaran Inovatif: Strategi Mengolah Kelas Secara Efektif dan Menyenangkan (Jogjakarta: Ar-Ruzz Media, 2014), h. 102

${ }^{12}$ Syaiful Bahri Djamarah dan Aswan Zain, Strategi Belajar mengajar, h. 157-158

${ }^{13}$ Slameto, Belajar dan Faktor yang mempengaruhinya. (Jakarta: Rineka Cipta, 2010 h. 180 
1) Pernyataan yang menunjukkan bahwa siswa lebih menyukai sesuatu daripada yang lainnya.

2) Partisipasi aktif dalam suatu kegiatan.

3) Perhatian yang lebih besar terhadap sesuatu yang diminati tanpa menghiraukan yang lain. ${ }^{14}$

Berdasarkan beberapa indikator yang telah dikemukakan di atas, penelitian ini menggunakan indikator minat sebagai berikut:

(a) Perhatian siswa dalam kegiatan belajar mengajar.

Perhatian siswa mempunyai peran penting dalam kegiatan belajar mengajar. Menurut Rusman, perhatian siswa terhadap pelajaran akan timbul apabila bahan pelajaran itu dirasakan sebagai sesuatu yang dibutuhkan. ${ }^{15}$ Selain itu, Yaumi mendefinisikan perhatian sebagai suatu sikap mental dalam memaknai peristiwa sensorik, mendeteksi tanda untuk proses fokus, dan mempertahankan kesiagaan terhadap peristiwa seperti keadaan serius, gairah belajar, tekun, dan semacamnya. ${ }^{16}$ Ciri-ciri siswa yang memiliki perhatian terhadap pembelajaran dirumuskan sebagai berikut:

- $\quad$ Fokus memperhatikan penjelasan guru dalam pembelajaran;

- $\quad$ Mencatat penjelasan guru;

- Membaca materi ajar;

- Serius dalam pelaksanaan tugas;

- $\quad$ Bersemangat mengerjakan tugas;

- Tekun dan tidak mudah putus asa dalam menyelesaikan tugas yang diberikan.

(b) Partisipasi aktif siswa dalam kegiatan belajar mengajar.

Sebuah pembelajaran seharusnya dapat mengaktifkan siswa dalam mengikuti pembelajaran dengan memberikan siswa kesempatan seluas-luasnya agar dapat mengembangkan rasa ingin tahunya. Berdasarkan prinsip student centered, maka peserta didik merupakan pusat dari suatu kegiatan belajar. Menurut Khanifatul, prinsip student

\footnotetext{
${ }^{14}$ Syaiful Bahri Djamarah dan Aswan Zain, Strategi Belajar Mengajar h.41

${ }^{15}$ Rusman, Belajar \& Pembelajaran Berorientasi Standar Proses Pendidikan Jakarta: Kencana, 2017), h. 94

${ }^{16}$ Muhammad Yaumi, Prinsip-prinsip Desain Pembelajaran disesuaikan dengan kurikulum 2013 (Jakarta: Kencana, 2017 h. 207
} 
centered menekankan bahwa proses pembelajaran akan lebih berhasil apabila siswa aktif dalam melakukan kegiatan-kegiatan yang sesuai dengan kompetensi pembelajaran yang hendak dicapai. ${ }^{17}$ Yaumi menyatakan bahwa keterlibatan aktif siswa dalam pembelajaran merupakan suatu tindakan responsif terhadap peristiwa. Beberapa bentuk partisipasi aktif siswa dalam pembelajaran adalah sebagai berikut:

- Menjawab pertanyaan guru;

- Bertanya kepada guru;

- Mengemukakan pendapat;

- $\quad$ Aktif melakukan pengamatan;

- $\quad$ Aktif mempresentasikan hasil pengamatannya;

- Menanggapi presentasi teman;

- Diskusi dengan anggota kelompoknya;

- Menyimpulkan hasil pembelajaran.

(c) Perasaan senang terhadap kegiatan belajar mengajar

Erwin Widiasworo menyatakan bahwa suatu pembelajaran dikatakan menarik apabila pembelajaran tersebut memerhatikan keseimbangan antara yang bersifat menyenangkan dan pemberian kesempatan untuk mengembangkan rasa ingin tahu seluas-luasnya demi menguasai kompetensi tertentu. ${ }^{18}$ Selanjutnya, Darmansyah menjelaskan bahwa apabila peserta didik mendapat rangsangan yang menyenangkan dari lingkungannya, maka akan membuat mereka lebih aktif dan kreatif secara mental dan fisik. ${ }^{19}$ Dengan demikian, perasaan senang siswa terhadap kegiatan pembelajaran merupakan suatu aspek penting yang perlu diperhatikan. Beberapa bentuk perasaan senang siswa yang dapat diamati adalah sebagai berikut:

- Masuk kelas tepat waktu;

- Membawa alat tulis dan buku;

- $\quad$ Mempunyai catatan materi ajar yang lengkap;

\footnotetext{
${ }^{17}$ Khanifatul, Pembelajaran Inovatif, h. 17

${ }^{18}$ Erwin Widiasworo, Strategi dan Metode Mengajar di Luar Kelas (Outdoor Learning): Secara Aktif, Kreatif, Inspiratif, dan Komunikatif (Yogyakarta: Ar-Ruzz Media, 2016), h. 17

${ }^{19}$ Khanifatul, Pembelajaran Inovatif, h. 37
} 
- $\quad$ Menyelesaikan tugas tepat waktu;

- Bertanggungjawab terhadap tugas;

- Tidak gelisah dalam belajar;

- Tidak mudah bosan dan menyerah dalam menyelesaikan tugas;

- Bersikap ceria.

Berikut adalah indikator minat belajar siswa serta bentuk tingkah laku yang akan diamati pada penelitian ini:

$$
\text { Tabel.1 }
$$

Indikator Minat Belajar Siswa

\begin{tabular}{|c|c|c|}
\hline No. & Indikator & Bentuk Tingkah Laku \\
\hline \multirow{6}{*}{1.} & \multirow{6}{*}{$\begin{array}{l}\text { Perhatian siswa } \\
\text { dalam kegiatan } \\
\text { belajar mengajar }\end{array}$} & $\begin{array}{l}\text { Fokus memperhatikan penjelasan guru } \\
\text { dalam pembelajaran }\end{array}$ \\
\hline & & Mencatat penjelasan guru \\
\hline & & Membaca materi ajar \\
\hline & & Serius dalam pelaksanaan tugas \\
\hline & & Bersemangat mengerjakan tugas \\
\hline & & $\begin{array}{l}\text { Tekun dan tidak mudah putus asa dalam } \\
\text { menyelesaikan tugas }\end{array}$ \\
\hline \multirow{8}{*}{2.} & \multirow{8}{*}{$\begin{array}{l}\text { Partisipasi aktif } \\
\text { siswa }\end{array}$} & Menjawab pertanyaan guru \\
\hline & & Bertanya kepada guru \\
\hline & & Mengemukakan pendapat \\
\hline & & Aktif melakukan pengamatan \\
\hline & & Aktif mempresentasikan hasil pengamatan \\
\hline & & Menanggapi presentasi teman \\
\hline & & Diskusi dengan anggota kelompoknya \\
\hline & & Menyimpulkan hasil pembelajaran \\
\hline \multirow{7}{*}{3.} & \multirow{7}{*}{$\begin{array}{l}\text { Perasaan senang } \\
\text { terhadap } \\
\text { kegiatan belajar } \\
\text { mengajar }\end{array}$} & Masuk kelas tepat waktu \\
\hline & & Membawa alat tulis dan buku \\
\hline & & $\begin{array}{l}\text { Mempunyai catatan materi ajar yang } \\
\text { lengkap }\end{array}$ \\
\hline & & Menyelesaikan tugas tepat waktu \\
\hline & & Bertanggungjawab terhadap tugas \\
\hline & & Tidak gelisah dalam belajar \\
\hline & & Tidak mudah bosan dan menyerah dalam \\
\hline
\end{tabular}




\begin{tabular}{|l|l|l|}
\hline & menyelesaikan tugas \\
& Bersikap ceria \\
\hline
\end{tabular}

Learning start with a question, yaitu suatu strategi pembelajaran yang proses belajarnya diarahkan agar siswa aktif dalam bertanya sebelum mendapatkan penjelasannya tentang materi yang akan dipelajari dari guru. Salah satu cara untuk membuat siswa belajar aktif adalah dengan membuat mereka bertanya tentang materi pelajaran sebelum ada penjelasan dari pengajar. ${ }^{20}$ Learning start with a question (LSQ) adalah suatu pembelajaran aktif dalam bertanya. Agar siswa dapat aktif bertanya maka siswa diminta untuk mempelajari materi yang akan dipelajarinya dengan bantuan membaca. Dengan membaca maka siswa memiliki gambaran tentang materi yang akan dipelajari, sehingga apabila dalam membaca atau membahas materi tersebut guru melakukan suatu proses, sehingga dapat terlihat beberapa persen siswa yang belajar dan yang tidak belajar. ${ }^{21}$ Jadi dapat peneliti simpulkan bahwa Learning start with a question merupakan suatu pembelajaran aktif dalam bertanya, dimana peserta didik dimulai dari pertanyaan-pertanyaan yang dapat merangsang peserta didik lebih semangat untuk belajar.

\section{B. Metodologi Penelitan}

Penelitian ini merupkan penelitian tindakan kelas (PTK) dengan pendektan kualitatif action research. PTK adalah sebuah penelitian yang dilakukan guru guna mengatasi permasalahan yang dihadapi dalam proses belajar-mengajar sehingga kualitas, minat dan hasil dalam pembelajaran dapat meningkat. Prosedur pelaksanaan PTK ini sesuai dengan prosedur yang telah dikemukakan oleh Kemmis dan Mc Taggart. Rancangan Kemmis \& Taggart dapat mencakup sejumlah siklus, masing-masing terdiri dari tahap-tahap: perencanaan (plan), pelaksanaan dan pengamatan (act \& observe), dan refleksi (reflect).

${ }^{20}$ Zaini Hisyam, Strategi Pembelajaran Aktif . (Yogyakarta: Pustaka Insan Madani, 2008), h. 44

${ }^{21}$ Ibid.h. 25 
Komponen tindakan (acting) dengan pengamatan (observing) disatukan dengan alasan kedua kegiatan itu tidak dapat dipisahkan. Maksudnya, kedua kegiatan harus dilakukan dalam satu kesatuan waktu, ketika tindakan dilaksanakan begitu pula observasi juga harus dilaksanakan ${ }^{22}$. Selain tindakan dan pengamatan yang digabungkan dalam satu aktivitas, pada model Kemmis \& Taggart terdapat adanya penekanan aktivitas perencanaan ulang (revised plan). Perencanaan ulang yang dikemukakan oleh kedua ahli ini menyatakan dimulainya siklus berikutnya dalam penelitian tindakan. ${ }^{23}$

Teknik pengumpulan data yang dilakukan dengan metode observasi, wawancata dan dokumentasi. Sedangkang teknik analisis data menggunakan menggunakan model Milles and Huberman, yaitu pengumpul data, reduksi data, penyajian data dan penarikan kesimpulan. ${ }^{24}$ Kriteria keberhasilan penelitian tentang minat belajar siswa $75 \%$ pada setiap indikator yang telah ditetapkan. Adapun indikator minat yang dimaksud dalam penelitian ini adalah.

1. Perhatian siswa dalam kegiatan belajar mengajar

2. Partisipasi aktif siswa

3. Perasaan senang terhadap kegiatan belajar mengajar.

Penelitian ini dikatakan berhasil apabila minat belajar siswa kelas x MIPA 2 Madrasah Aliyah Negeri 1 Bungo materi hiwayah memperoleh rentang $75 \%$ ke atas dari semua indikator minat belajar siswa atau dengan kriteria Cukup.

\section{Temuan dan Pembahasan}

Temuan penelitian

\section{Pra siklus}

Penelitian ini diwali dengan melakukan observasi untuk mengamati belajar siswa pada mata pelajaran bahasa arab kelas $\mathrm{x}$ MIPA 2 Madrasah Aliyah Negeri 1 Bungo dengan perolehan Perhatian

\footnotetext{
${ }^{22}$ Wijaya Kusumah dan Dedi Dwitagama, Mengenal Penelitian Tindakan Kelas (Jakarta: PT Indeks, 2011), cet. 2, h. 20

${ }^{23}$ Benidiktus Tanujaya dan Jeinne Mumu, Penelitian Tindakan Kelas: Panduan Belajar, Mengajar, dan Meneliti (Yogyakarta: Media Akademi, 2016), h. 22

${ }^{24}$ Ibid, h. 102
} 
siswa dalam kegiatan belajar mengajar 45,78 \%, Partisipasi aktif siswa 35,075 \% Perasaan senang terhadap kegiatan belajar mengajar 59,675. jadi ketercapaian pada pra siklus adalah sebesar $47,17 \%$, yang mana berada pada kriteria sangat kurang

\section{Siklus I}

Siklus I pertemuan pertama dilaksanaan sesuai dengan prosedur yang telah dikemukakan oleh Kemmis dan Mc Taggart. Kegiatan yang dilakukan terdiri dari tahap-tahap: perencanaan (plan), pelaksanaan dan pengamatan (act \& observe), refleksi (reflect), dan perencanaan ulang.

\section{Perencanaan}

Pada tahap perencanaan ini peneliti menyiapkan Rencana Pelaksanaan Pembelajaran (RPP) serta menyiapkan teknik dan instrument observasi minat siswa.

\section{Pelaksanaan dan Pengamatan}

Pelaksanaan pada siklus I pertemuan pertama dilakukan pada tanggal 8 Maret 2021 selama tiga jam pelajaran, jam pembelajaran ini di sesuaikan dengan instruksi Mendikbud, penetapan jam pembelajaran pada masa pademi covid 19. Kegiatan pembelajaran dilaksanakan sesuai dengan RPP yang telah dibuat. Tema yang diajarkan adalah Hiwayah.

\section{a) Kegiatan pendahuluan}

- Mengawali pembelajaran dengan mengucapkan salam, dan berdoa

- Mengecek kehadiran siswa.

- Menyampaikan tujuan pemnelajaran

- Apersepsi .

b) Kegiatan inti

- Memberikan penjelasan materi tentang Hiwayah dan kaitannya dalam kehidupan sehari-hari.

- Merangsang siswa untuk bertanya terlebih dahulu

- Memberi waktu siswa untuk bertanya

- Melemparkan jawaban terlebih dahulu kepada siswa

- Merangkum jawaban-jawaban siswa dan

- Guru menjelaskan tetang pertanyaan-pertanyaan dari siswa. 


\section{c) Kegiatan Penutup}

- Mengingatkan kambali materi yang telah disampaikan

- Memberi penguatan dan kesikmpulan.

- Malakukan penilain cara objektif.

Pada tahap observasi peneliti melakukan pengamatan dalam menggunakan strategi learning start with a question (LSQ) pada kelas online sesuai dengan lembaran obsevasi yang telah disiapkan sebelumnya. Persentase minat belajar siswa pada mata pelajaran bahasa arab secara klasikal sebesar $52,15 \%$, yang mana berada pada kriteria sangat kurang.

\section{Refleksi}

Selama pelaksanaan tindakan siklus I pertemuan 1, pembelajaran masih belum sesuai dengan aspek-aspek indikator yang telah ditetapkan sebelumnya. Aspek-aspek tersebut yang belum terlaksana dengan baik. Adapun aspek-aspek yang dimaksud adalah, perhatian siswa dalam kegiatan belajar mengajar 49,96\%, partisipasi aktif siswa 34,7 dan perasaan senang terhadap kegiatan belajar mengajar 62,8\%. Hal ini belum sesuai dengan capaian minat belajar siswa yaitu 75 \% dari masing-masing indikator. Melihat hasil capaian minat belajar siswa masih kurang maka perlu melakukan perbaikan pada pertemuan II.

\section{Perencanaan Ulang}

Berdasarkan hasil refleksi yang pada siklus I pertemuan 1 maka perencanaan ulang yang peneliti lakukan yaitu penerapan strategi learning start with a question (LSQ) dengan memotivasi siswa membawa objek yang dipelajari ke dalam dunia nyata, serta membatasi lokasi pengamatan siswa dalam menyelesaikan tugas. Hal ini diharapkan dapat memudahkan dalam melakukan pengontrolan, serta menghemat waktu pembelajaran.

Pertemuan kedua pada siklus I dilakukan pada tanggal 15 Maret 2021 selama tiga jam 3 pelajaran. Kegiatan pembelajaran dilaksanakan sesuai dengan RPP yang telah dibuat. tema yang diajarkan adalah Hiwayah dengan materi qira'ah 


\section{Perencanaan}

Pada tahap perencanaan ini peneliti mengindentifikasi masalah pada pertemuan pertama, menyiapkan Rencana Pelaksanaan Pembelajaran (RPP) serta menyiapkan teknik dan strategi LSQ serta instrument observasi minat siswa.

\section{Pelaksanaan dan Pengamatan}

1. Kegiatan pendahuluan

- Mengawali pembelajaran dengan mengucapkan salam, dan berdoa

- $\quad$ Mengecek kehadiran siswa.

- Menyampaikan tujuan pemnelajaran

- Apersepsi .

2. Kegiatan inti.

- Memberikan penjelasan materi kaitannya dalam kehidupan sehari-hari.

- $\quad$ Merangsang siswa untuk bertanya sesuai dengan strategi $L S Q$

- Memberi waktu siswa untuk bertanya

- Melemparkan jawaban terlebih dahulu kepada siswa

- Merangkum jawaban-jawaban siswa dan

- Guru menjelaskan tetang pertanyaan-pertanyaan dari siswa.

3. Kegiatan Penutup.

- $\quad$ Mengingatkan kambali materi yang telah disampaikan

- $\quad$ Memberi penguatan materi

- Malakukan penilain cara objektif.

- $\quad$ Dan di tutup dengan do'a

\section{Refleksi}

Pada pelaksanaan tindakan siklus I pertemuan kedua, minat belajar siswa sudah mulai meningkat tapi masih belum sesuai dengan aspek-aspek indikator yang telah ditetapkan. Aspek-aspek tersebut yang belum terlaksana dengan baik. Adapun aspek-aspek yang dimaksud adalah, perhatian siswa dalam kegiatan belajar mengajar 70,3\%, partisipasi aktif siswa $71,125 \%$ dan perasaan senang terhadap kegiatan belajar mengajar 74,93\%. Hal ini belum sesuai dengan capaian minat belajar siswa yaitu 75 \% dari masing-masing indikator. Melihat hasil capaian minat belajar siswa masih kurang maka perlu melakukan perbaikan pada sikus II. 
Perencanaan Ulang.

Berdasarkan hasil refleksi yang pada siklus I pertemuan II maka perencanaan ulang yang peneliti lakukan yaitu penerapan strategi learning start with a question (LSQ) dengan minat siswa membawa objek yang dipelajari ke dalam dunia nyata, serta membatasi lokasi pengamatan siswa pada pastisipasi aktif siswa. Hal ini diharapkan dapat memudahkan dalam melakukan pengontrolan, serta menghemat waktu pembelajaran.

\section{Siklus II}

Pelaksanaan pada siklus II pertemuan pertama dilakukan pada tanggal 22 Maret 2021 selama tiga jam pelajaran. Kegiatan pembelajaran dilaksanakan sesuai dengan RPP yang telah dibuat. Tema yang diajarkan adalah Hiwayah dengan materi hiwar.

a. Kegiatan pendahuluan

- Mengawali pembelajaran dengan mengucapkan salam, dan berdoa

- Mengecek kehadiran siswa.

- Menyampaikan tujuan pemnelajaran

- Apersepsi .

b. Kegiatan inti.

- Memberikan penjelasan materi tentang Hiwayah dan kaitannya dalam kehidupan sehari-hari.

- Merangsang siswa untuk bertanya terlebih dahulu

- Memberi waktu siswa untuk bertanya

- Melemparkan jawaban terlebih dahulu kepada siswa

- Merangkum jawaban-jawaban siswa dan

- Guru menjelaskan tetang pertanyaan-pertanyaan dari siswa.

c. Kegiatan Penutup.

- Mengingatkan kambali materi yang telah disampaikan

- Memberi penguatan dan kesikmpulan.

- Malakukan penilain cara objektif.

Pada tahap observasi peneliti melakukan pengamatan dalam menggunakan strategi learning start with a question (LSO) pada kelas online sesuai dengan lembaran obsevasi yang telah disiapkan sebelumnya. Persentase minat belajar siswa pada mata pelajaran 
bahasa arab secara klasikal sebesar $77,23 \%$, yang mana berada pada kriteria cukup.

\section{Refleksi}

Selama pelaksanaan tindakan siklus II pertemuan 1, sudah ada kemajuan yang sangat siknifikan, dimana para siswa sudah menampakan minat belajarnya namun sungguh demikian masih belum mencapai aspek-aspek indikator yang telah ditetapkan sebelumnya. Adapun aspek-aspek yang dimaksud adalah, perhatian siswa dalam kegiatan belajar mengajar 77,28 \%, partisipasi aktif siswa $73,57 \%$ dan perasaan senang terhadap kegiatan belajar mengajar 80,86\%. Hal ini belum sesuai dengan capaian minat belajar siswa yaitu 75 \% dari masing-masing indikator. Melihat hasil capaian minat belajar siswa pada indikator partisipasi siswa masih kurang maka perlu melakukan perbaikan pada pertemuan II.

\section{Perencanaan Ulang}

Hasil refleksi yang pada siklus II pertemuan 1 maka perencanaan ulang yang peneliti lakukan yaitu penerapan strategi learning start with a question (LSQ) dengan menggunakan beberapa metode untuk meningkatkan minat belajar siswa menfokuskan pada partisifasi siswa. Hal ini diharapkan dapat memudahkan dalam melakukan pengontrolan, serta menghemat waktu pembelajaran.

Pelaksanaan pada siklus II pertemuan kedua dilakukan pada tanggal 29 Maret 2021 selama tiga jam pelajaran. Kegiatan pembelajaran dilaksanakan sesuai dengan RPP yang telah dibuat. Tema yang diajarkan adalah Hiwayah, dengan materi al-kitabah

1) Kegiatan pendahuluan

- Mengawali pembelajaran dengan mengucapkan salam, dan berdoa

- Mengecek kehadiran siswa.

- Menyampaikan tujuan pemnelajaran

- Apersepsi .

2) Kegiatan inti.

- Memberikan penjelasan materi tentang Hiwayah dan kaitannya dalam kehidupan sehari-hari.

- Merangsang siswa untuk bertanya terlebih dahulu

- Memberi waktu siswa untuk bertanya 
- Melemparkan jawaban terlebih dahulu kepada siswa

- Merangkum jawaban-jawaban siswa dan

- Guru menjelaskan tetang pertanyaan-pertanyaan dari siswa.

3) Kegiatan Penutup.

- Mengingatkan kambali materi yang telah disampaikan

- Memberi penguatan dan kesikmpulan.

- Malakukan penilain cara objektif.

Pada tahap observasi peneliti melakukan pengamatan selama pelaksanaan tindakan siklus II pertemuan kedua, sudah menunjukan kemajuan yang sangat siknifikan, dimana para siswa sudah menampakan minat belajarnya dan telah mencapai aspek-aspek indikator yang telah ditetapkan. Persentase minat belajar siswa pada mata pelajaran bahasa arab secara klasikal sebesar 81,26\%, yang mana berada pada kriteria baik.

Refleksi.

Berdasarkan hasil observasi selama pelaksanaan tindakan siklus II pertemuan kedua menunjukkan perubahan pada beberapa aspek yang kurang maksimal pada pelaksanaan tindakan siklus II pertemuan 1. Perubahan tersebut diuraikan sebagai berikut.

(a) Peneliti bisa menarik perhatian siswa untuk lebih serius mengikuti proses pembelajaran;

(b) Peneliti terlihat sudah bisa mengkondisikan kelas online dan mempersiapkan siswa untuk belajar;

(c) Siswa aktif untuk menanyakan hal-hal yang bersangkutan dengan materi;

(d) Siswa aktif berdiskusi dan melakukan pengamatan;

(e) Siswa aktif mempresentasikan hasil pengamatan;

(f) Minat belajar siswa telah mencapai target, yakni $75 \%$ pada masing-masing indikator.

\section{Perencanaan Ulang}

Berdasarkan hasil refleksi yang dilakukan pada siklus II pertemuan 2 di atas, minat belajar siswa telah mencapai $81,26 \%$. Hal ini menunjukkan minat belajar siswa telah mencapai target yang ditetapkan sebelumnya, yakni $75 \%$ pada masing-masing indikator. Berdasarkan data tersebut, dapat disimpulkan bahwa menggunakan 
strategi learning start with a question (LSQ) pada kelas online pada tema hiwayah dapat meningkatkan minat belajar siswa. Oleh sebab itu, penelitian pada siklus II ini dikatakan berhasil sehingga penelitian tindakan dihentikan dan tidak dilanjutkan pada siklus selanjutnya.

\section{Pembahasan}

Penelitian tindakan kelas ini dilaksanakan dalam dua siklus. Siklus I dilaksanakan dalam dua kali pertemuan, dan Siklus II dilaksanakan dalam dua kali pertemuan. Kegiatan observasi dilakukan pada setiap pertemuan dengan menggunakan lembaran observasi guna mengetahui peningkatan minat belajar siswa. Berdasarkan tindakan yang telah dilaksanakan dengan menggunakan strategi learning start with a question (LSO) dapat meningkatkan minat belajar siswa di kelas x pada mata pelajaran bahasa arab Tema "Hiwayah" di Madrasah Aliyah Negeri 1 Bungo, maka penelitian ini dikatakan berhasil karena telah mencapai indikator keberhasilan tindakan yang telah ditetapkan yaitu memperoleh nilai $75 \%$ pada semua indikator minat belajar siswa.

Minat belajar siswa dalam pembelajaran dapat dilihat dari tiga indikator, yaitu perhatian siswa dalam kegiatan belajar mengajar. Menurut Yaumi perhatian siswa sebagai suatu sikap mental dalam memaknai peristiwa sensorik, mendeteksi tanda untuk proses fokus, dan mempertahankan kesiagaan terhadap peristiwa seperti keadaan serius, gairah belajar, tekun, dan semacamnya. ${ }^{25}$ Kemudian partisipasi aktif siswa. Menurut Thobroni dan Mustofa, siswa sebagai subjek belajar dituntut aktif mencari, menemukan, menganalisis, merumuskan, memecahkan masalah, dan menyimpulkan. Partisipasi aktif siswa dalam pembelajaran yaitu, menjawab pertanyaan guru, bertanya kepada guru, mengemukakan pendapat, aktif melakukan pengamatan, aktif mempresentasikan hasil pengamatanya, menanggapi presentasi teman, diskusi dengan anggota kelompoknya, menyimpulkan hasil pembelajaran dan perasaan senang siswa

${ }^{25}$ Muhammad Yaumi, Prinsip-Prinsip Desain Pembelajaran, h. 207 
terhadap pembelajaran ${ }^{26}$. Indikator perasaan senang siswa terhadap pembelajaran pada penelitian ini merupakan indikator yang mengalami peningkatan yang cukup signifikan. Erwin Widiasworo menyatakan bahwa suatu pembelajaran dikatakan menarik apabila pembelajaran tersebut memerhatikan keseimbangan antara yang bersifat menyenangkan dan pemberian kesempatan untuk mengembangkan rasa ingin tahu seluas-luasnya demi menguasai kompetensi tertentu. ${ }^{27}$ Perasaan senang siswa yang dapat diamati adalah tepat waktu, mempunyai alat tulis dan buku, mempunyai catatan materi ajar, menyelesaikan tugas tepat waktu, bertanggungjawab, tidak gelisah dalam belajar, tidak mudah bosan dan bersikap ceria. Peningkatan minat belajar siswa pada masingmasing siklus dapat dilihat pada tabel berikut ini:

Tabel 2

Peningkatan Minat Belajar Siswa

Pra Siklus Siklus I dan Siklus II

\begin{tabular}{|c|c|c|c|c|c|c|}
\hline \multirow{2}{*}{ No. } & \multirow{2}{*}{$\begin{array}{c}\text { Indikator Minat } \\
\text { Belajar }\end{array}$} & \multirow{2}{*}{ Pra Siklus } & \multicolumn{2}{|c|}{ Siklus I } & \multicolumn{2}{|c|}{ Siklus II } \\
\hline & & & P. 1 & P. 2 & P. 1 & P. 2 \\
\hline 1 & Perhatian Siswa & 45,78 & $\begin{array}{c}49,9 \\
6\end{array}$ & 70,3 & 77,28 & 81,41 \\
\hline 2 & $\begin{array}{l}\text { Partisipasi Aktif } \\
\text { Siswa }\end{array}$ & 36,075 & 43,7 & $\begin{array}{c}71,12 \\
5\end{array}$ & 73,57 & 76,68 \\
\hline 3 & Perasaan Senang & 59,675 & 62,8 & 74,93 & 80,86 & 85,71 \\
\hline \multicolumn{2}{|c|}{ Rata-rata Klasikal } & 47,17 & $\begin{array}{c}52,1 \\
5\end{array}$ & 72,11 & 77,23 & 81,26 \\
\hline \multicolumn{2}{|c|}{ Rata-rata Per Siklus } & 47,17 & \multicolumn{2}{|c|}{62,13} & \multicolumn{2}{|c|}{79,25} \\
\hline
\end{tabular}

\section{Penutup}

Penelitian tindakan kelas yang dilakukan di Madrasah Aliyah Negeri 1 Bungo dapat disimpulkan pertama dengan menggunakan

\footnotetext{
${ }^{26}$ Muhammad Thobroni, Arif Mustofa, Belajar dan Pembelajaran: Pengembangan Wacana dan Praktik Pembelajaran dalam Pembangunan Nasional (Jogjakarta: Ar-Ruzz Media, 2011), h. 18

${ }^{27}$ Erwin Widiasworo, Strategi dan Metode Mengajar di Luar Kelas , h. 17
} 
strategi learning start with a question (LSQ) dapat meningkatan minat belajar siswa pada pembelajaran bahasa arab. Hal ini terlihat dalam hasil penelitian yang menunjukkan minat belajar siswa telah mencapai indikator keberhasilan penelitian yaitu $75 \%$ pada setiap indikator minat belajar siswa. Rata-rata minat belajar siswa pada pra siklus adalah 47,17\%. Pada siklus I, rata-rata minat belajar siswa adalah $62,13 \%$ atau pada kriteria kurang dan pada siklus II yaitu $79,25 \%$ atau pada kriteria cukup. Kedua, Indikator yang mengalami peningkatan yang cukup signifikan adalah indikator perasaan senang siswa terhadap pembelajaran. Rata-rata perasaan senang siswa terhadap kegiatan belajar mengajar pada pra siklus adalah 59,675\%. Pada siklus I, perasaan senang siswa terhadap pembelajaran adalah $68,865 \%$, dan meningkat mencapai $83,285 \%$ pada siklus II.

Berdasarkan hasil penelitian ini, bagi pendidik untuk meningkatan minat belajar siswa pada pembelajaran dapat menggunakan strategi learning start with a question (LSQ). Dan yang paling penting dalam menggunakan strategi learning start with a question pendidikan harus dapat mempersiapkan dengan sebaik mungkin agar pembelajaran dapat berjalan sesuai dengan rencana yang tertuang dalam RPP.

\section{Daftar Pustaka}

Baharuddin dan Esa Nur Wahyuni, Teori Belajar \& Pembelajaran Yogyakarta, Ar-Ruzz Media, 2015

Benidiktus Tanujaya dan Jeinne Mumu, Penelitian Tindakan Kelas: Panduan Belajar, Mengajar, dan Meneliti Yogyakarta: Media Akademi, 2016

Dedi Mulyasana, Pendidikan Bermutu dan Berdaya Saing, Bandung: Remaja Rosdakarya, 2012

Erwin Widiasworo, Strategi dan Metode Mengajar di Luar Kelas (Outdoor Learning): Secara Aktif, Kreatif, Inspiratif, dan Komunikatif Yogyakarta: Ar-Ruzz Media, 2016 
H. Cholil dan Sugeng Kurniawan, Psikologi Pendidikan; Telaah Teoritik dan Praktik, Surabaya: IAIN Sunan Ampel Press, 2011

Khanifatul, Pembelajaran Inovatif: Strategi Mengolah Kelas Secara Efektif dan Menyenangkan Jogjakarta: Ar-Ruzz Media, 2014

Muhammad Thobroni dan Arif Mustofa, Belajar dan Pembelajaran: Pengembangan Wacana dan Praktik Pembelajaran dalam Pembangunan Nasional Jogjakarta: Ar-Ruzz Media, 2011

Muhammad Yaumi, Prinsip-prinsip Desain Pembelajaran disesuaikan dengan kurikulum 2013 Jakarta: Kencana, 2017

Ngainun Naim, Dasar-dasar Komunikasi Pendidikan Jogjakarta: Ar-Ruzz Media, 2011

Prawira Purwa Atmaja, Psikologi Pendidikan dalam Perspektif Baru Jogjakarta: Ar-Ruzz Media, 2014

Rusman, Belajar \& Pembelajaran Berorientasi Standar Proses Pendidikan Jakarta: Kencana, 2017

Slameto, Belajar dan Faktor yang mempengaruhinya. Jakarta: Rineka Cipta, 2010

Suyono dan Hariyanto, Belajar dan Pembelajaran: Teori dan Konsep Dasar, Bandung: Remaja Rosdakarya, 2012.

Syaiful Bahri Djamarah dan Aswan Zain, Strategi Belajar Mengajar, Jakarta: Rineka Cipta, 2013

Teguh Triwiyanto, Pengantar Pendidikan, Jakarta:PT Bumi Aksara, 2014

Wijaya Kusumah dan Dedi Dwitagama, Mengenal Penelitian Tindakan Kelas Jakarta: PT Indeks, 2011, cet. 2,

Yatim Riyanto, Paradigma Baru Pembelajaran : sebagai Referensi bagi Guru/Pendidik dalam Implementasi Pembelajaran yang Efektif dan Berkualitas (akarta: Prenada Media Group, 2014), cet. 4

Zaini Hisyam, Strategi Pembelajaran Aktif . Yogyakarta: Pustaka Insan Madani, 2008 